\title{
PERAN KELOMPOK TANI TERHADAP PENDAPATAN PETANI PADI SAWAH DI DAERAH IRIGASI TEKNIS KECAMATAN KAMBERA KABUPATEN SUMBA TIMUR
}

\author{
THE ROLE OF FARMER GROUPS ON THE INCOME OF RICE FARMERS \\ IN THE TECHNICAL IRRIGATION AREA KAMBERA \\ SUB-DISTRICT EAST SUMBA DISTRICT
}

\author{
Ferdinand Mangutu Kiki*, Elfis Umbu Katongu Retang, Junaedin Wadu
}

\author{
Program Studi Agribisnis, Fakultas Sains dan Teknologi, Universitas Kristen Wira Wacana Sumba \\ Jl. R. Suprapto, No 35, waingapu, Sumba Timur, NTT \\ *Email: Ferdinandkiki252@gmail.com \\ (Diterima 26-10-2021; Disetujui 22-01-2022)
}

\begin{abstract}
ABSTRAK
Penelitian ini bertujuan untuk mengetahui peran kelompok tani terhadap pendapatan petani padi sawah di daerah irigasi teknis Kecamatan Kambera Kabupaten Sumba Timur. Penelitian ini dilakukan selama 2 bulan dari bulan Mei hingga bulan juli 2021. Data yang digunakan dalam penelitian ini adalah data primer dan data sekunder. Hasil penelitian ini menunjukkan peran kelompok tani sebagai kelas belajar memperoleh skor 312 dengan kategori berperan, peran kelompok tani sebagai wadah kerjasama memperoleh skor 286 dengan kategori cukup berperan, dan peran kelompok tani sebagai unit produksi memperoleh skor 257 dengan kategori cukup berperan. Berdasarkan hasil rekapitulasi peran kelompok tani memperoleh rata-rata skor 287 yang menunjukkan bahwa kelompok tani cukup berperan sebagai kelas belajar, wadah kerjasama, dan unit produksi. Sedangkan pendapatan petani padi sawah dapat dilihat dengan menggunakan analisis pendapatan. hasil penelitian menunjukkan rata-rata biaya yang dikeluarkan petani sebesar $\mathrm{Rp}$ 10.256.325,00/ha dan penerimaan sebesar Rp 20. 185.818,00/ha sehingga pendapatan petani padi sawah di daerah irigasi teknis Kecamatan Kambera sebesar Rp10.525.493,00/ha. Untuk mengetahui peran kelompok tani terhadap pendapatan maka digunakan uji korelasi rank spearman dengan menggunakan SPSS.16, yang menunjukkan peran kelompok tani berpengaruh signifikan terhadap pendapatan petani padi sawah. Semakin ditingkatkan peran kelompok tani maka akan meningkatkan pendapatan petani padi sawah di daerah irigasi teknis Kecamatan Kambera.
\end{abstract}

Kata kunci: peran, kelompok tani, padi sawah, pendapatan

\begin{abstract}
This studi aims to determine the role of farmer groups on the income of rice farmers in the technical irigation area Kambera District East Sumba Regency. This research was conducted for 2 months from may to july 2021. The data used in this study are primary data and secondari data. The result of this study indicate the role of farmer groups as a learning class to get a score of 312 with a role category. The role of farmer groups as a forum for cooperation received a score of 286 in the category of quite role and the role of farmer groups as a production unit scored 257 in the category of playing a sufficient role.based on the results of the recapitulation of the role of farmer groups, it obtained a score of 287 which indicates that the farmer groups have quite a role as a learning class, a forum for cooperation and production unit. While the incomes of rice farmers can be seen by using income analysis. The resultsof this study indicate that the average cost incurred by farmers is Rp.10.256.325,00/ Ha and ravenue of Rp.20185.818,00/ Ha so that the income of rice farmers in the technical irrigation area of the Kambera sub-district is Rp.10.525.493,00/Ha. To determinate the role of farmer groups on income, the spearman rank correlation test was used using SPSS.16 which showed that the role of farmer groups had a significant effect on the income
\end{abstract}


of lowland rice farmers. The more the role of farmer groups is increased, it will increased the income of rice farmers in the technical irrigation area of the Kambera Sub-district.

Keywords: role, farmers, rice paddy, income

\section{PENDAHULUAN}

Padi sebagai komoditas pangan utama yang berperan penting dalam pemenuhan kebutuhan karbohidarat bagi penduduk dan juga memiliki nilai ekonomis yang tinggi sehingga diperlukan suatu upaya dalam peningkatannya. Upaya untuk meningkatkan produktivitas padi tidak terlepas dari peran pemerintah dalam menyediakan bantuan bagi para petani. Salah satu cara pemerintah membantu perkembangan pertanian di Indonesia yaitu dengan melakukan pembentukan kelembagaan pertanian yang berperan penting dalam dalam memenuhi kebutuhan petani seperti menyediakan fasilitas yang dibutuhkan oleh petani (sarana produksi), meningkatkan posisi tawar menawar petani dalam kegiatan ekonomi, sehingga dapat mengurangi kesenjangan dan kerugian yang dialami oleh petani (Pradana, 2013).

Kabupaten Sumba Timur memiliki produksi padi sawah sebesar 68.917,07 ton dan produktivitas sebesar 5,84 ton/ha dengan luas panen padi sawah sebesar 16.678,44 ha (BPS Kabupaten Sumba Timut 2019). Pada tahun 2015
Kecamatan Kambera memiliki produksi padi sawah sebesar 1.177 ton dari luas lahan 382 ha dengan produktivitas 3,08/ ha. Pada tahun 2016 Kecamatan Kambera memiliki produksi padi sawah sebesar 3.84 ton dari luas lahan 918 ha dengan produktivitas 4,13/ha, sedangkan pada tahun 2017 Kecamatan Kambera memiliki produksi padi sawah 3.84 ton dari luas lahan 918 ha dengan produktivitas 4,19/ha (BPS Kabupaten Sumba Timur 2015-2017).

Berdasarkan data di atas terlihat bahwa Kecamatan Kambera memiliki tingkat produksi padi sawah yang cenderung meningkat dari tahun 2015 sampai 2017. Menurut BP3K Kecamatan Kambera 2017, peningkatan produksi ini terjadi karena kelompok tani semakin maju dan berkembang. Berdasarkan Permentan Nomor 67/ Permentan/ SM.050/12/2016, kelompok tani memiliki tiga peran dan fungsi strategis yaitu sebagai kelas belajar, wahana kerja sama dan unit produksi. Kelompok tani sebagai kelas belajar adalah wadah belajar dalam kelompok tani guna meningkatkan perilakunya agar tumbuh dan berkembang menjadi usahatani yang 
mandiri sehingga dapat meningkatkan produktivitas, pendapatan serta kehidupan yang lebih baik. Wahana kerja sama merupakan bagian dari peran kelompok tani yang memungkinkan petani untuk memperkuat kerja sama dengan baik di antara sesama petani dalam poktan dan antar poktan maupun dengan pihak lain. Kelompok tani sebagai unit produksi merupakan sebagai satu kesatuan usaha yang dapat dikembangkan untuk mencapai skala ekonomis usaha, dengan menjaga kuantitas, kualitas maupun kontinuitas.

Keberadaan kelompok tani dapat memudahkan kelompok tani dalam menjalankan usahatani karena dalam kelompok tani adanya pelatihan untuk meningkatkan ketrampilan dan kemampuan petani, menyediakan input produksi yang dibutuhkan oleh petani serta membantu petani dalam pemasaran hasil produksi sehingga dapat meningkatkan pendapatan petani (Prasetya, 2013). Berdasarkan uraian di atas peneliti tertarik meneliti peran kelompok tani terhadap pendapatan petani padi sawah di daerah irigasi teknis Kecamatan Kambera Kabupaten Sumba Timur.

\section{METODE PENELITIAN}

Penelitian ini dilaksanakan di Kecamatan Kambera, Kabupaten Sumba Timur. Pemilihan lokasi penelitian ini dilakukan secara purposive dengan pertimbangan Kecamatan Kambera merupakan daerah yang dialiri irigasi teknis Bendungan Kambaniru, memiliki kelompok tani yang berprestasi dan sering mendapatkan penghargaan, sebagian besar masyarakatnya bekerja pada sektor pertanian padi sawah dan merupakan salah satu daerah penghasil padi sawah terbanyak di Kabupaten Sumba Timur. Penelitian ini dilakukan pada bulan November sampai dengan Desember 2020.

Populasi dalam penelitian ini terdiri atas petani padi sawah yang tergabung dalam kelompok tani. Meliputi ketua dan anggota kelompok tani padi sawah di daerah irigasi teknis yang berada di Kecamatan Kambera Kabupaten Sumba Timur yang berjumlah 32 kelompok tani dan memiliki jumlah anggota keseluruhan sebesar 940 petani. Pertimbangan bahwa jumlah populasi yang besar jumlahnya sehingga tidak memungkinkan untuk meneliti seluruh populasi yang ada, maka dilakukan pengambilan sampel. Menurut (Sugiyono, 2012), sampel adalah bagian 
dari jumlah dan karaktertistik yang dimiliki oleh populasi. Untuk menghitung penentuan jumlah sampel dari populasi di daerah irigasi teknis Kecamatan Kambera, maka digunakan rumus Slovin. Perhitungan pengambilan sampel menggunakan rumus Slovin sebagai berikut:

$n=\frac{N}{n \cdot\left(d^{2}\right)+1}$

dimana:

$\mathrm{n}=$ ukuran sampel

$\mathrm{N}=$ Populasi

$\mathrm{d}=$ taraf nyata atau batasan kesalahan $(10 \%)$

Berdasarkan rumus di atas, maka besar sampel dapat dihitung sebagai berikut:

$$
\begin{aligned}
\mathrm{n} & =\frac{940}{940(0,01)+1} \\
& =\frac{940}{10.4} \\
& =90.38 \text { dibulatkan menjadi } 90 \text { petani }
\end{aligned}
$$

Jadi sampel yang digunakan dalam peneltian ini adalah 90 petani padi sawah di daerah irigasi teknis Kecamatan Kambera.

Data primer adalah data yang diperoleh dengan cara observasi dan wawancara langsung dengan responden menggunakan daftar pertanyaan yang telah disusun sesuai dengan tujuan penilitian. Data sekunder adalah data yang diperlukan untuk menunjang data primer yang diperoleh dari studi kepustakaan, dan instansi-instansi terkait seperti BP3K Kecamatan Kambera dan Pandawai dan Dinas Pertanian Kabupaten Sumba Timur maupun BPS Kabupaten Sumba Timur.

\section{Analisis Pendapatan}

Soekartawi 1995 mengatakan bahwa pendapatan usahatani merupakan selisih antara penerimaan dengan semua biaya yang dikeluarkan dalam melakukan usahatani. Penerimaan usahatani merupakan perkalian antara produksi dengan harga jual, sedangkan biaya merupakan semua pengeluaran yang dikeluarkan dalam usahatani. Adapun rumus untuk menghitung pendapatan sebagai berikut :

$\mathrm{I}=\mathrm{TR}-\mathrm{TC}$

Keterangan :

I = Pendapatan

$\mathrm{TR}=$ Total Penerimaan

$\mathrm{TC}=$ Total Biaya

\section{Analisis peran kelompok tani}

Untuk mengetahui peran kelompok tani terhadap pendapatan petani padi sawah di daerah irigasi teknis kecamatan Kambera, digunakan alat analisis statistik nonparametrik dengan metode skoring. Pemberian skor yang digunakan adalah teknik skala likert. Penggunaan skala likert menurut (Sugiyono, 2013) 
digunakan untuk mengukur sikap, pendapat dan persepsi seseorang atau sekelompok orang tentang fenomena sosial. Dalam metode ini, setiap kriteria yang akan dinilai diberikan skor. Data primer didapat dengan mengamati serta menilai peran kelompok tani berdasarkan aspek penilaian peran kelompok tani. Skor peran kelompok tani akan dibagi menjadi lima kelas dengan panjang kelas interval yang sama. Menurut Sugiyono (2013), untuk menentukan panjang interval suatu kelas digunakan rumus:

$\mathrm{P}=$ Rentang : Kelas

Bobot skor minimal setiap indikator adalah 1 dan bobot maksimalnya adalah 5, dengan jumlah sampel 90 orang maka skor total minimal adalah 90 dan skor maksimal adalah 450. Dengan demikian dapat dihitung panjang interval setiap kelasnya sebagai berikut:

$\mathrm{P}=(450-90): 5=360: 5=72$

Dari perhitungan di atas diperoleh panjang interval tiap kelasnya adalah 72 , dengan demikian pembagian kelas masing-masing interval dapat dilihat pada Tabel 1 .

Tabel 1. Pembagian kelas dan tingkatan peran kelompok tani berdasarkan interval

\begin{tabular}{ccl}
\hline Interval & \multicolumn{1}{c}{ Kelas } & \multicolumn{1}{c}{ Tingkatan } \\
\hline 72 & $90-162$ & Tidak sangat berperan \\
72 & $162-234$ & Tidak berperan \\
72 & $234-306$ & Cukup berperan \\
72 & $306-378$ & Berperan \\
72 & $378-450$ & Sangat berperan \\
\hline
\end{tabular}

\section{HASIL DAN PEMBAHASAN}

\section{Karakteristik Responden}

1. Umur

Salah satu karakteristik yang digunakan dalam penelitian ini adalah umur responden. Umur petani berpengaruh terhadap kemampuan fisik seseorang dalam bekerja. Semakin tua umur petani maka kemampuan kerja akan cenderung menurun dan akan berpengaruh terhadapan produksi yang dihasilkan. Menurut (Lalu, 2018) umur seseorang dapat mempengaruhi kemampuan dan prestasi bekerjanya serta mempengaruhi tingkat kematangan seseorang yang sangat menentukan kesiapannya dalam usahatani. Umur petani sampel dapat dilihat pada Tabel 2.

Tabel 2. Umur

\begin{tabular}{cccc}
\hline No. & $\begin{array}{c}\text { Umur } \\
\text { (tahun) }\end{array}$ & $\begin{array}{c}\text { Jumlah } \\
\text { (orang) }\end{array}$ & $\begin{array}{c}\text { Presentase } \\
(\%)\end{array}$ \\
\hline 1. & $20-55$ & 58 & 65 \\
2. & $56-70$ & 32 & 35 \\
\hline & Jumlah & 90 & $100 \%$
\end{tabular}

Sumber: Data primer diolah, 2021

Umur responden dalam usahatani padi sawah di daerah irigasi teknis Kecamatan kambera berkisar antara 20 sampai 70 tahun. Umur 20-55 tahun berjumlah 58 orang dengan angka presentase $65 \%$ dan umur 56-70 tahun berjumlah 38 orang dengan angka persentase mencapai 35\%. Kelompok umur petani di daerah irigasi teknis Kecamatan Kambera menunjukan bahwa 
petani padi sawah yang memiliki umur produktif lebih tinggi dengan presentase 65\% dibandingkan dengan kelompok umur non produktif yang hanya $35 \%$. Menurut (Zuriani, 2017), pengelompokan umur usia produktif adalah mereka yang berada pada kelompok umur 15-55 tahun. Pada usia produktif kemampuan untuk melakukan usahatani diperkirakan masih relatif tinggi. Hal ini menunjukkan bahwa petani padi sawah di daerah irigasi teknis Kecamatan Kambera memiliki umur yang produktif sehingga kemampuan untuk melakukan usahatani masih relatif tinggi. Dengan demikin semakin tinggi umur produktif petani maka akan semakin mempengaruhi kemampuan bekerja sehingga pendapatan yang diperoleh dalam berusahatani semakin tinggi

\section{Tingkat pendidikan}

Pendidikan merupakan suatu hal yang penting dimana dengan adanya pendidikan yang pernah diikuti oleh petani secara langsung akan mempengaruhi pola pikir dan pengetahuan (Fahmi, 2019).Tingkat pendidikan merupakan salah satu faktor yang dapat mempengaruhi petani dalam menerima sebuah inovasi dan teknologi dibidang pertanian. Semakin rendah tingkat pendidikan petani maka semakin lambat petani tersebut dapat menyerap sebuah perkembangan teknologi dan kemampuan menerima inovasi baru, begitu juga sebaliknya semakin tinggi pendidikan petani maka akan mempercepat penyerapan atau menerima setiap perkembangan teknologi dan inovasi-inovasi. Tingkat pendidikan dapat dilihat pada Tabel 3.

Tabel 3. Tingkat Pendidikan

\begin{tabular}{clcc}
\hline No. & Pendidikan & $\begin{array}{c}\text { Jumlah } \\
\text { (orang) }\end{array}$ & $\begin{array}{c}\text { Presentase } \\
(\mathbf{\%})\end{array}$ \\
\hline 1. & SD & 53 & 58,8 \\
2. & SMP & 28 & 31,1 \\
3. & SMA & 8 & 8,8 \\
4. & Sarjana & 1 & 1,1 \\
\hline & Jumlah & $\mathbf{9 0}$ & $\mathbf{1 0 0}$ \\
\hline
\end{tabular}

Sumber: Data Primer diolah, 2021

Berdasarkan Tabel 3, tingkat pendidikan petani responden tertingi adalah SD mencapai (58\%), kemudian SMP mencapai $(31,1 \%)$, dan setelah itu SMA mencapai $(8,8 \%)$, dan yang paling rendah adalah sarjana yaitu mencapai (1,1\%). Dengan demikian, berdasarkan kelompok pendidikan di atas tingkat pendidikan responden yang melakukan usahatani di daerah irigasi teknis Kecamatan kambera masih tergolong rendah sehingga menyebabkan kurang terserapnya inovasi-inovasi yang berkaitan dengan usahatani padi sawah di Kecamatan Kambera. Tingkat pendidikan yang dimiliki oleh petani menunjukan tingkat pengetahuan serta wawasan petani dalam menerapkan teknologi 
maupun inovasi baru untuk meningkatkan usahatani.

3. Pengalaman Berusahatani

Menurut (Lalu, 2018), pengalaman berusahatani merupakan proses belajar yang dapat mempermudah adopsi dan penerapan teknologi dan pengembangan usahatani. Pengalaman juga dapat mempengaruhi kemampuan petani dalam berusahatani. Semakin lama petani memiliki pengalaman maka dapat menambah keterampilan dalam meningkatkan hasil produksi yang baik (Wengkau,et al, 2017). Pengalaman berusahatani dapat dilihat pada Tabel 4 .

Tabel 4. Pengalaman Berusahatani

\begin{tabular}{cccc}
\hline No. & $\begin{array}{c}\text { Pengalaman } \\
\text { (tahun) }\end{array}$ & $\begin{array}{c}\text { Jumlah } \\
\text { (orang) }\end{array}$ & $\begin{array}{c}\text { Presentase } \\
\mathbf{( \% )}\end{array}$ \\
\hline 1. & $0-10$ & 11 & 12.2 \\
2. & $11-20$ & 32 & 35.6 \\
3. & $21-30$ & 43 & 47.8 \\
\hline & Jumlah & $\mathbf{9 0}$ & $\mathbf{1 0 0}$ \\
\hline
\end{tabular}

Sumber: Data Primer diolah, 2021

Berdasarkan Tabel 4 dapat dilihat bahwa pengalaman responden yang melakukan usahatani padi sawah di daerah irigasi teknis Kecamatan Kambera yang mencapai 20-30 tahun sebesar 47\%, dan yang mencapai 11-20 tahun sebesar $35,6 \%$ dan 1-10 tahun sebesar 12,2\%. (Lalu, 2018) semakin lama petani melakukan usahataninya maka akan semakin meningkatkan kemampuan petani dalam mengelola usahataninya. Pengalaman berusahatani yang cukup lama menjadikan petani lebih matang dan lebih berhati-hati, dalam mengambil keputusan terhadap usahataninya (Soekartawi, 2006).

\section{Luas Lahan}

Luas lahan merupakan media yang digunakan oleh anggota kelompok tani dalam menjalankan kegiatan usahatani padi sawah di daerah irigasi teknis diukur dengan satuan hektar (ha). Besar kecilnya jumlah produksi petani tergantung dari luasnya lahan, petani yang memiliki lahan yang luas biasanya selalu menghasilkan produksi yang besar pula (Suardana et al, 2013). Luas lahan responden padi sawah di daerah irigasi teknis Kecamatan Kambera dapat dilihat pada Tabel 5.

\begin{tabular}{cccc}
\multicolumn{2}{l}{ Tabel 5. Luas Lahan } \\
\hline No & $\begin{array}{c}\text { Luas lahan } \\
\text { (ha) }\end{array}$ & $\begin{array}{c}\text { Jumlah } \\
\text { (orang) }\end{array}$ & $\begin{array}{c}\text { Presentase } \\
\text { (\%) }\end{array}$ \\
\hline 1. & $0,1-0,5$ & 76 & 84.4 \\
2. & $0,6-0,8$ & 8 & 8.9 \\
3. & $0,9-1$ & 6 & 6.7 \\
\hline & Jumlah & $\mathbf{9 0}$ & $\mathbf{1 0 0}$
\end{tabular}

Sumber: Data Primer diolah, 2021

\section{Berdasarkan Tabel 5 petani} responden yang memiliki luas lahan 0,10,5 ha mencapai $(84,4 \%)$, untuk luas lahan 0,6-0,8 mencapai (8.9\%), dan luas lahan 0,9-1 ha mencapai (6.7\%). berdasarkan data di atas dapat disimpulkan bahwa rata-rata responden memiliki luas lahan yang diusahakan masih terbilang sempit paling banyak 


\section{PERAN KELOMPOK TANI TERHADAP PENDAPATAN PETANI PADI SAWAH \\ DI DAERAH IRIGASI TEKNIS KECAMATAN KAMBERA KABUPATEN SUMBA TIMUR \\ Ferdinand Mangutu Kiki, Elfis Umbu Katongu Retang, Junaedin Wadu}

sehingga dapat menimbulkan produksi yang tidak besar. Menurut (Agus, et al., 2019) semakin luas lahan yang dikelola petani maka akan semakin besar produksi yang dihasilkan sehingga dapat memberikan nilai lebih besar pada pendapatan petani.

\section{Analisis Biaya, Penerimaan dan Pendapatan}

\section{Biaya}

Usahatani padi sawah di daerah irigasi teknis tidak terlepas dari biayabiaya yang dikeluarkan untuk menghasilkan produksi. Adapun biaya dalam usahatani padi sawah (Agus, et al., 2019) yaitu biaya tetap (Fixed Cost) dan biaya variabel (Variable Cost). Biaya tetap adalah biaya yang relatif tetap jumlahnya dan tidak bergantung pada besar kecilnya produksi. Biaya tetap petani padi sawah didaerah irigasi teknis Kecamatan Kambera meliputi pajak lahan, penyusutan alat (sabit, cangkul, sprayer dan mesin seperti rontok dan hand tractor. Sedangkan biaya Variabel adalah biaya yang besar kecilnya dipengaruhi oleh produksi yang diperoleh meliputi biaya pembelian benih, pupuk, pestisida dan tenaga kerja.
Tabel 6. Rata-rata Biaya

\begin{tabular}{clr}
\hline No & Biaya Usahatani & Total Rp/ha \\
\hline 1. & Biaya Tetap & \\
& - Pajak & 116.816 .00 \\
& - Biaya punyusutan alat & 387.754 .00 \\
& $\quad$ dan mesin & 504.570 .00 \\
& Jumlah biaya tetap & \\
2. & Biaya Variabel & \\
& - Pupuk & 1.100 .525 .00 \\
& - Pestisida & 470.902 .000 \\
& - Herbisida & 93.921 .00 \\
& - Tenaga kerja & 7.490 .409 .00 \\
& Jumlah biaya variabel & $9.751 .755,00$ \\
3. & Biaya Total & 10.256 .325 .00 \\
\hline Sumber: Data Primer Diolah 2021
\end{tabular}

Sumber: Data Primer Diolah 2021

Tabel 6 menunjukkan bahwa ratarata biaya usahatani yang dikeluarkan anggota kelompok tani padi sawah didaerah irigasi teknis Kecamatan Kambera sebesar Rp 10.256.325.000 yang terdiri atas biaya tetap dan biaya variabel. Biaya tetap sebesar Rp504.570.00/ha yang digunakan untuk biaya penyusutan alat dan mesin, sedangkan biaya variabel adalah biaya yang digunakan atau dikeluarkan untuk usahatani padi sawah dalam 1 musim tanam Rp9.751.755,00/ha yang meliputi biaya pembelian pupuk, pestisida herbisida dan pembayaran tenaga kerja.

\section{Penerimaan}

Besarnya penerimaan yang diperoleh petani dipengaruhi oleh besarnya jumlah produksi yang dihasilkan petani dan harga jual yang sesuai dengan maka semakin besar pula penerimaan yang diperoleh petani (Made, et al., 2013). Penerimaan usahatani padi 
sawah di daerah irigasi teknis Kecamatan Kambera merupakan hasil perkalian antara produksi yang diperoleh dengan harga jual, sehingga penerimaan ditentukan oleh besar kecilnya produksi yang dihasilkan anggota kelompok tani dengan harga jual. Rata-rata produksi gabah di daerah irigasi teknis kecamatan Kambera sebesar 3.9 ton/ha dengan ratarata harga jual gabah $\mathrm{Rp} 5.239,00 / \mathrm{kg}$ sehingga diperoleh rata-rata penerimaan Rp20.185,818/ha.

\section{Pendapatan}

Menurut (Sosilo et al. 2019) pendapatan merupakan selisih antara penerimaan dengan total biaya yang dikeluarkan selama satu musim tanam. Tabel 7 menunjukkan rata-rata pendapatan usahatani padi sawah petani responden di daerah irigasi teknis kecamatan Kambera sebesar Rp. 10.525.493,00/ha.

Tabel 7. Rata-rata Pendapatan

\begin{tabular}{lr}
\hline \multicolumn{1}{c}{ Uraian } & Total $(\mathbf{R p} / \mathbf{h a})$ \\
\hline Penerimaan usahatani & \\
- Produksi gabah $(\mathrm{Kg} / \mathrm{Ha})$ & $3.943 \mathrm{Kg} / \mathrm{Ha}$ \\
- Harga gabah $(\mathrm{Rp} / \mathrm{Kg})$ & $5.239,00$ \\
Jumlah Penerimaan $(\mathrm{Rp} / \mathrm{Ha})$ & $20.185 .818,00$ \\
Biaya-biaya & \\
- Biaya tetap $(\mathrm{Rp} / \mathrm{Ha})$ & 504.570 .00 \\
- Biaya variabel $(\mathrm{Rp} / \mathrm{Ha})$ & $9.751 .755,00$ \\
Jumlah biaya/Ha & 10.256 .325 .00 \\
Pendapatan petani/ Ha & $10.525 .493,00$ \\
\hline Sumber: Data Primer Diolah 2021 &
\end{tabular}

Rata-rata produksi gabah kering yang dihasilkan anggota kelompok tani dalam melakukan usahatani padi sawah di daerah irigasi teknis selama 1 musim tanam yaitu 3.9 ton/ha dan rata-rata harga jual gabah kering sebesar Rp5.239,00/kg. Sehingga jumlah penerimaan yang didapatkan petani adalah sebesar Rp20.185.815,00/ha. Pendapatan yang diperoleh petani merupakan hasil pengurangan antara total penerimaan dengan total biaya yang dikeluarkan dalam satu musim tanam. Total rata-rata pendapatan yang diperoleh anggota kelompok tani padi sawah di daerah irigasi teknis kecamatan Kambera sebesar Rp10.525.493,00/ha. Pendapatan petani responden di daerah penelitian cukup besar sehingga jika dikonversikan pendapatan petani setiap bulan maka ratarata pendapatan petani di daerah irigasi teknis Kecamatan Kambera sebesar Rp3.508.497,00 per usahatani.

\section{Peran Kelompok Tani}

\section{Kelas belajar}

Kelas belajar merupakan wadah bagi anggota kelompok tani untuk belajar guna meningkatkan pengetahuan, keterampilan dan sikap agar tumbuh dan berkembang menjadi usahatani yang mandiri sehingga meningkatkan produktivitas dan pendapatan serta kehidupan yang lebih baik (Romario, et al., 2019). Berdasarkan hasil penelitian 


\section{PERAN KELOMPOK TANI TERHADAP PENDAPATAN PETANI PADI SAWAH \\ DI DAERAH IRIGASI TEKNIS KECAMATAN KAMBERA KABUPATEN SUMBA TIMUR \\ Ferdinand Mangutu Kiki, Elfis Umbu Katongu Retang, Junaedin Wadu}

yang telah dilakukan, variabel peran kelompok tani sebagai kelas belajar di daerah irigasi teknis Kecamatan Kambera termasuk dalam kategori "Berperan" dimana skor rata-rata yang diperoleh sebesar 312. Hal ini menggambarkan bahwa peran kelompok tani sebagai kelas belajar di daerah irigasi teknis Kecamatan
Kambera berjalan dengan baik, peran kelompok tani dapat dilihat dari 7 indikator yang digunakan dalam penelitian untuk mengukur seberapa besar peran kelompok tani sebagai kelas belajar. Adapun peran kelompok tani di daerah irigasi teknis kecamatan Kambera dapat dilihat pada Tabel 8 .

Tabel 8. Peran kelompok tani sebagai kelas belajar

\begin{tabular}{clcl}
\hline No. & \multicolumn{1}{c}{ Variabel } & Skor & \multicolumn{1}{c}{ Interprestasi } \\
\hline 1. & ketika bergabung kelompok tani mendapatkan pelatihan & 316 & Berperan \\
2. & Kelompok tani selalu aktif berdiskusi & 290 & Cukup berperan \\
3. & Dapat menumbuh kembangkan potensi yang dimiliki & 310 & Berperan \\
4. & Terdapat kemandirian dalam menjalankan usahatani & 315 & Berperan \\
5. & Mendapatkan pengarahan dari penyuluh & 304 & Cukup berperan \\
6. & Dalam berkelompok tani adanya pertemuan secara berkala & 338 & Berperan \\
\hline & Rata-rata & 312 & Berperan \\
\hline
\end{tabular}

Sumber: data primer diolah 2021

\section{Wadah kerja sama}

Wahana kerja sama merupakan tempat kelompok tani untuk memperkuat kerja sama baik di antara sesama petani dalam kelompok tani dan antar kelompok tani maupun dengan pihak lain, melalui kerja sama diharapkan usahatani lebih efisien dan lebih mampu menghadapi ancaman, tantangan, hambatan dan gangguan, serta lebih menguntungkan (Rinaldi, et al., 2015). Kelompok tani di daerah irigasi teknis Kecamatan Kambera dalam menjalankan perannya sebagai wadah kerjasama bagi anggota kelompok, pengurus kelompok, harus mampu memperkuat dan sekaligus memperlancar dan sekaligus mendorong terwujudnya kerjasama yang saling menguntungkan, peran kelompok tani sebagai wadah kerjasama di Kecamatan Kambera diperoleh rata-rata skor sebesar 286 dengan kategori "cukup berperan”. Peran kelompok tani sebagai wadah kerjasama dapat diukur dengan beberapa indikator seperti pada Tabel 9.

Tabel 9. Peran Kelompok Tani Sebagai Wadah Kerjasama.

\begin{tabular}{clcc}
\hline No. & \multicolumn{1}{c}{ Variabel } & Skor & Interprestasi \\
\hline 1. & Kelompok tani menciptakan suasana kerjasama & 248 & Cukup berperan \\
2. & $\begin{array}{l}\text { Kelompok tani berkerjasama mengahadapi ancaman, hambatan } \\
\text { maupun tantangan dalam berusahatani }\end{array}$ & 226 & Tidak berperan \\
3. & $\begin{array}{l}\text { Kelompok tani terdapat kerjasama antara anggota kelompok dalam } \\
\text { pembagian tugas }\end{array}$ & 307 & Berperan \\
4. & Adanya saling terbuka, saling mengenal dan saling percaya dalam & 318 & Berperan
\end{tabular}


kelompok

5. Ketika bergabung dalam kelompok tani terdapat kerjasama dengan $330 \quad$ Berperan penyedia sarana dan jasa produksi.

Sumber : data primer diolah 2021 Rata-rata

$286 \quad$ Cukup berperan

\section{Unit Produksi}

Peran kelompok tani sebagai penyedia unit produksi adalah kemampuan kelompok dalam menyediakan sarana dan prasarana dalam menunjang kegiatan anggotanya sehingga mampu meningkatkan skala ekonomis usaha yang dijalankan oleh kelompok dengan menjaga kuantitas dan kontiunitas (Rinaldi, et al., 2015). Tabel 10 menunjukkan bahwa variabel peran kelompok tani sebagai wahana unit produksi diperoleh rata-rata skor sebesar 257 degan kategori "cukup berperan”.

Tabel 10. Peran kelompok tani sebagai unit produksi

\begin{tabular}{clcc}
\hline No. & \multicolumn{1}{c}{ Variabel } & Skor & Interprestasi \\
\hline 1. & Kelompok tani menyusun dan melaksanakan kebutuhan kelompok tani & 244 & cukup berperan \\
2. & Memfasilitasi penerapan teknologi (bahan, alat dan cara) bagi anggota & 247 & Cukup berperan \\
& kelompok & 257 & Cukup berperan \\
3. & Mengevaluasi kegiatan bersama & 280 & Cukup berperan \\
4. & Mengembangkan dan meningkatkan produksi anggota kelompok & 258 & Cukup berperan \\
5. & Pengelolaan admistrasi dalam kelompok tani & 257 & Cukup berperan \\
\hline & Rata-rata &
\end{tabular}

Sumber: data primer diolah 2021

\section{Rekapitulasi Peran Kelompok Tani}

Rekapitulasi peran kelompok tani bertujuan untuk mengukur peran kelompok tani padi sawah di Kecamatan Kambera yang dapat dilihat dari 3 peran kelompok tani yaitu peran kelompok tani sebagai kelas belajar, wadah kerjasama dan unit produksi dengan jumlah indikator keseluruhan peran kelompok tani sebanyak 16 indikator. Hal ini sejalan dengan penelitian (Romario, et al., 2019) yang melakukan rekapitulasi peran kelompok tani di Kelolendai Indah di Desa Ampreng Kecamatan Longowan Barat untuk mengetahui peran kelompok tani.

Peran kelompok tani di Kecamatan Kambera yaitu sebagai kelas belajar, sebagai wadah kerjasama dan sebagai unit produksi, dengan jumlah 16 indikator sebagai tolak ukur dalam penelitian ini. Tabel 10. Menunjukkan rekapitulasi peran kelompok tani di daerah irigasi teknis Kecamatan Kambera. 


\section{PERAN KELOMPOK TANI TERHADAP PENDAPATAN PETANI PADI SAWAH \\ DI DAERAH IRIGASI TEKNIS KECAMATAN KAMBERA KABUPATEN SUMBA TIMUR \\ Ferdinand Mangutu Kiki, Elfis Umbu Katongu Retang, Junaedin Wadu}

Tabel 10. Rekapitulasi Peran Kelompok Tani

\begin{tabular}{clcl}
\hline No. & \multicolumn{1}{c}{ Indikator Peran Kelompok Tani } & Skor & Keterangan \\
\hline 1. & Ketika bergabung dalam kelompok tani mendapatkan pelatihan. & 316 & Berperan \\
2. & Kelompok tani selalu aktif berdiskusi & 290 & Cukup berperan \\
3. & Dapat menumbuh kembangkan potensi yang dimiliki & 310 & Berperan \\
4.. & Terdapat kemandirian dalam menjalankan usahatani & 315 & Berperan \\
5. & Mendapatkan pengarahan dari penyuluh pertanian & 304 & Cukup berperan \\
6. & Adanya pertemuan berkala & 338 & Berperan \\
7. & Kelompok tani menciptkan suasana kerjasama & 248 & Cukup berperan \\
8. & Bekerjasama menghadapi ancaman, tantangan dan hamabatan & 226 & Tidak berperan \\
9. & Adanya kerjasama anggota kelompok dalam pembagian tugas & 307 & Berperan \\
10. & Adanya saling terbuka, saling mengenal dan saling percaya & 318 & Berperan \\
11. & Terdapat kerjasama dalam penyedia sarana produksi & 330 & Berperan \\
12. & Kelompok tani menyusun dan melaksanakan kebutuhan kelompok & 244 & Cukup berperan \\
13. & Memfasilitasi penerapan teknologi & 247 & Cukup berperan \\
14. & Mengevaluasi kegiatan bersama & 257 & Cukup berperan \\
15. & Mengembangkan dan meningkatkan produksi & 280 & Cukup berperan \\
16. & Adanya pengelolaan administrasi yang baik dalam kelompok tani & 258 & Cukup berperan \\
\cline { 2 - 4 } & Rata-rata & 287 & Cukup berperan \\
\cline { 2 - 4 }
\end{tabular}

Sumber: data primer diolah 2021

Berdasarkan Tabel 10 dapat diketahui peran kelompok tani di daerah irigasi teknis Kecamatan Kambera Kabupaten Sumba Timur dengan menghitung jumlah skor pada setiap indikator. Jumlah skor hasil penelitian tentang peran kelompok tani di Kecamatan Kambera mencapai jika di rata-ratakan mencapai 287. Dalam penelitian ini memiliki jumlah skor ideal tertinggi yaitu 450 degan kategori "sangat berperan" dan jumlah skor ideal terendah yaitu 90 dengan kategori "sangat tidak berperan". Berdasarkan hasil penelitian yang diperoleh peran kelompok tani di daerah irigasi teknis Kecamatan Kambera mencapai skor 287 dengan kategori "Cukup Berperan". Meskipun masih terdapat 1 indikator yang tidak berperan. Hal ini karena petani cenderung menghadapi ancaman, hamabatan dan tantangan secara individu. tidak ada kerja sama dalam menghadapi ancaman, hambatan maupun tantangan dalam usahatani padi sawah. Hal ini sejalan dengan penelitian (Romario, et al., 2019) yang menyatakan bahwa peran kelompok tani Desa Ampreng Kecamatan Lengowan Barat dalam mengembangkan usahatani secara bersama tidak baik dilaksanakan karena yang lebih menonjol adalah secara individu.

\section{Hubungan Peran Kelompok Tani Terhadap Pendapatan Petani.}

Untuk melihat hubungan antara peran kelompok tani dengan pendapatan petani padi sawah di daerah irigasi teknis Kecamatan Kambera maka digunakan analisis korelasi Rank Spearman dengan menggunakan SPSS. 


\begin{tabular}{lllrr}
\hline & & Peran Kelompok Tani & Pendapatan \\
\hline Spearman's rho & Peran Kelompok Tani & Correlation & 1.000 & $.238^{*}$ \\
& & Coefficient & & .024 \\
& Sig. (2-tailed) & 90 & 90 \\
& $\mathrm{~N}$ & $.238^{*}$ & 1.000 \\
& Pendapatan & Correlation & .024 &. \\
& Coefficient & 90 & 90 \\
& Sig. (2-tailed) & $\mathrm{N}$ & &. \\
& & $\mathrm{N}$ &
\end{tabular}

Sumber : data primer diolah 2021

Peran kelompok tani terhadap pendapatan petani padi sawah di daerah irigasi teknis Kecamatan Kambera dapat diketahui dari nilai signifikansi sebesar 0,024 atau $<0,05$ sehingga ada hubungan yang siginifikan antara antara peran kelompok tani terhadap pendapatan pendapatan petani padi sawah di daerah irigasi teknis Kecamatan Kambera. Nilai koefisien korelasi sebesar 0,238, artinya tingkat kekuatan hubungan (korelasi) antara variabel peran kelompok tani sebagai kelas belajar, wadah kerjasama dan unit produksi terhadap pendapatan sebesar 0,238 atau korelasi lemah. Sedangkan angka koefisien korelasi bernilai positif yakni sebesar 0,238 sehingga kedua variabel tersebut searah, dengan demikian dapat diartikan bahwa peran kelompok tani semakin ditingkatkan maka akan meningkatkan pendapatan petani padi sawah di daerah irigasi teknis Kecamatan Kambera. Hal ini sejalan dengan penelitian (Yuliawati, et al., 2019) yang menyatakan bahwa peran kelompok tani sebagai kelas belajar, wadah kerja sama dan unit produksi berpengaruh signifikan terhadap pendapatan petani padi sawah di Kelurahan Kauman Kidul, Kecamatan Siderejo, Kota Salatiga.

\section{KESIMPULAN DAN SARAN \\ Kesimpulan}

1. Rata-rata pendapatan yang diperoleh anggota kelompok tani padi sawah di daerah irigasi teknis Kecamatan Kambera yaitu sebesar $\mathrm{Rp}$ 10.525.493,00/ha. Pendapatan petani di daerah irigasi teknis Kecamatan Kambera jika dikonversikan pendapatan petani setiap bulan maka rata-rata pendapatan petani sebesar Rp 3.508.497,00 per usahatani.

2. Peran kelompok tani berpengaruh signifikan terhadap pendapatan petani padi sawah di daerah irigasi teknis Kecamatan Kambera. Semakin 
ditingkatkan peran kelompok tani maka akan meningkatkan pendapatan petani padi sawah di daerah irigasi teknis Kecamatan Kambera.

\section{Saran}

1. Peran kelompok tani perlu ditingkatkan lagi dalam kegiatan kelas belajar, wadah kerjasama dan unit produksi terhadap pendapatan kelompok tani padi sawah di daerah irigasi teknis Kecamatan Kambera agar benar-benar tercapai peran kelompok tani terhadap pendapatan anggotanya.

2. Peran kelompok tani sebagai wadah kerjasama antara anggota kelompok perlu ditingkatkan lagi.

\section{DAFTAR PUSTAKA}

Agus , S., Junaedi \& Abd, A., 2019. Pengaruh Luas Lahan, Biaya Produksi dan Harga Pasar Terhadap Peningkatan Pendapatan Petani Bawang Merah di Kabupaten Bogor. Journal Of Public Power, Volume 3. Nomor 1, pp. 12-28.

Badan Pusat Statistik.( 2019). Kambera dalam angka. Kabupaten Sumba Timur.

Balai Penyuluhan Pertanian Perikanan dan Kehutanan Kecamatan Kambera.https://sumbatimurkab.bp s.go.id/publication/2019/09/26/3a9 1b1d01119ca089c119c34/kecamata n-kambera-dalam-angka-2019.html

Lalu, M. S., 2018. Pengaruh Karakteristik Petani Terhadap Pendapatan
Usahatani Jagung. Buletin

Penelitian Tanaman Sereallia,

Volume 2, pp. 1-6.

Pradana, Adhi Putu Bagus Ida. 2013. Peran Kelembagaan Dalam Pengembangan Usaha Tani Sayuran Organik di Kelompok Tani Trianggulasi, Desa Batur, Kecamatan Getasan Kabupaten Semarang. Skripsi. Universitas Kristen Satya Wacana. Salatiga.

Rinaldi, P., Tubagus, H. \& Begem, I., 2015. Peranan Kelompok Tani Dalam Peningkatan Pendapatan Petani Kopi di Kelurahan Tugusari Kecamatan Sumber Jaya. JIA, Volume 3, pp. 301-307

Romario, E. P., Charles, R. N. \& Ben, L. S., 2019. Peran Kelompok Tani Terhadap Anggota Kelompok Tani Kelelondei Indah di Desa Ampreng Kecamatan Longowan Barat. Agri Sosial Ekonomi Unsrat, Volume 1, pp. 37-44.

Sugiyono (2012). Memahami Penelitian Kualitatif. Bandung : ALFABETA

Wengkau I. M, Max, N, A, Effendy. (2017). "Analisis Pendapatan Usahatani Padi Sawah Dengan Pola Jajar Legowo Di Desa Sidera Kecamatan Sigi Biromaru Kabupaten Sigi Sulawesi Tengah", program studi agribisnis. Fakultas pertanian. Universitas tadulako. Palu.

Yuliawati, Lolita \& Geofanny, P., 2019. Peran Kelompok Tani Terhadap Pendapatan Petani Padi Sawah di Kelurahan Kauman Kidul Kecamatan Kota Siderejo Kota Salatiga. Agritech, Volume 2, pp. 131-139.

Zuriani, 2017. Keterkaitan dan Dampak Karakteristik Sosial Petani Terhadap Produksi Padi di Kabupaten Aceh Utara. Jurnal Agrifo, Volume 2, pp. 312-715 